\title{
Magazine Based On Guided Inquiry-An Innovation to Overcome Natural Science Learning Difficulties in Elementary Schools
}

\author{
Ika Maryani ${ }^{1}$, Nurul Wahyu Lestari ${ }^{2}$, Much. Fuad Saifuddin ${ }^{3}$
}

1 Ika Maryani, M. Pd. Ahmad Dahlan University, Department of Elementary School Teacher Education, Jl. Ki Ageng Pemanahan, Yogyakarta, Indonesia, ika.maryani@pgsd.uad.ac.id.

2 Nurul Wahyu Lestari, S. Pd. Ahmad Dahlan University, Department of Elementary School Teacher Education, Jl.

Ki Ageng Pemanahan, Yogyakarta, Indonesia, nurulwahyu241@gmail.com

3 Much. Fuad Saifuddin, M. Pd. Ahmad Dahlan University, Department of Biology Education, Indonesia, Jl.

Ringroad Selatan, Tamanan, Yogyakarta, Indonesia, fuad.saifuddin@pbio.uad.ac.id

\begin{abstract}
This study was aimed at developing a feasible magazine based on the guided inquiry for 5th-grade elementary schools. The development procedure adopted was the Hannafin and Peck model which involves needs assessment, design, development, evaluation, and revision. Data were collected through the use of questionnaires and tests. It analyzed using descriptive statistics and interactive qualitative analysis. This research produced science magazines which are feasible to be used as instructional media towards overcoming learning difficulties and enhancing students' understanding.
\end{abstract}

Keywords: science magazine, guided inquiry, elementary school.

\section{Introduction}

Natural Science is one of the compulsory primary subjects for students from the 1st to 6 th grade included in the national examination of elementary schools in Indonesia. This makes it an important element determining the success of the learning activities undertaken by the students. However, several factors have been reported to be affecting students' academic performance in Natural Science learning and these include motivation (Hossainy, Zare, Hormozi, Shaghaghi, \& Kaveh, 2013; Perangin-angin \& Effendy, 2016), teaching facilities (Mushtaq \& Khan, 2012), student engagement (Reyes, Brackett, 
Rivers, White, \& Salovey, 2012), students' social and emotion (Durlak et al., 2011), teachers teaching methods (Devine, Fahie, \& Deirdre, 2013), and the presence or absence of cognitive barriers such as learning difficulties (Maryani, Husna, Wangid, Mustadi, \& Vahechart, 2018). Moreover, the level of difficulty for the learning material being studied in the lower grades $\left(1^{\text {st }}, 2^{\text {nd }}\right.$, and $\left.3^{\text {rd }}\right)$ and upper ones $\left(4^{\text {th }}, 5^{\text {th }}\right.$, and $6^{\text {th }}$ grades $)$ is different.

It is possible to detect and resolve these difficulties early and this has led to the implementation of several actions tailored to the needs, characters, and attention to the variations in the attributes of elementary school students by the teachers. For example, it has been reported these students tend to play, happy to move around, enjoy working in groups, and feeling or doing things directly (Koerber, Mayer, Osterhaus, Schwippert, \& Sodian, 2015; Kunter et al., 2013) and it is important to consider these attributes while preparing an effective and meaningful learning process.

Based on previous works of research conducted on Natural Science learning in elementary schools of Indonesia, several problems have been identified and these include emphasis of several teachers on learning by memory factor (Sinaga, Karniawati, \& Setiawan, 2017), inadequate implementation of laboratory experiments prioritizing thinking skills (Parmin, Sajidan, Ashadi, Sutikno, \& Maretta, 2016), focus on lectures presentation with limited activities thereby leading to only listening and copying (Zubaidah, Fuad, Mahanal, \& Suarsini, 2017), and decrease in teaching performance of Natural Science teachers during preparation, materials delivery, learning methods, and media selection, students management, and learning evaluations (Dewi, Bundu, \& Tahmir, 2016). Moreover, field observations showed students' involvement in learning activities is low, for example, when a teacher explains a material, the students are usually silent, and this means they are less interested in certain learning materials due to their difficult and complex characteristics.

Media has been reported to have an important role in improving the quality of the process of learning Natural Science at elementary schools (Livingstone \& Bovill, 2013). Therefore, it is expected to be selected with due consideration for conformity with learning objectives and methods, student's circumstances, availability, and efficiency. This is because appropriate media has the ability to optimize the utilization of human senses in capturing several materials (Ramdhani \& Muhammadiyah, 2015) towards creating meaningful learning. It provides the students with more access to constructive knowledge by learning through the things around in relation to their cognitive structure. The type of media selected can also help the visualization of abstract concepts such as in the explanation of something considered too small, too large, or even harmful in order to ensure effective comprehension of the learning materials (Cohen, Ebeling, \& Kulik, 1981; Korakakis, Georgios, Palyvos, \& Spyrellis, 2009). Some examples of media applicable in the teaching and learning process include visual, photographic images, projection, audio, and three-dimensional media, as well as the surrounding environment (Nurseto, 2011).

There are several advantages of applying these learning media in teaching and learning activities. First, the reminiscence of the media has the ability to clarify the presentation of 
messages and knowledge, thus facilitating and improving the training process. Second, it enhances and directs the children's attention to generate motivation, direct interaction with setting, and permission to discover their ability and interests. Third, it overcomes the constraints of the senses, space, and time, and lastly, it provides students with similar experiences regarding events in their setting and permission for direct interaction with lecturers, communities, and several other environments assessed through field, repository, or facility visits (Clark, Yates, Early, \& Moulton, 2008; Nurseto, 2011).

The type of media applied in learning activities in collaboration with appropriate strategies can be an effective way to improve students' understanding of a subject. For example, the appropriate application of interesting media has the capacity to increase students' interest, engagement, and involvement in the acquisition of knowledge. This is further expected to have more implications such as increasing activeness, knowledge, curiosity, confidence, etc. (Sinatra, Heddy, \& Lombardi, 2015).

In the process of teaching Natural Science, the strategies to be used need to have the capacity to provide a meaningful learning process for the students and one of the methods usually employed is the Inquiry Learning Strategy. It is a series of activities emphasizing the essential and analytical thinking method required to discover and notice the answers to the matter in a question (Gillies \& Nichols, 2015). This media is integrated to ensure students conduct direct actions and interact directly with all the components involved in the entire learning process.

Inquiry strategy focuses on the ability to think critically on the context of learning material and also helps students develop the skills to discover certain concepts such as distinctive queries and ideas regarding scientific phenomena through the investigation and scientific explanation of cases. It has also been discovered to have the ability to help students the possible application of Natural Science in real life. Moreover, the collaborative inquiry method has the ability to train students in using a collective approach to solve problems, measuring their ability, and assisting their peers in need of assistance. This, however, makes this media very important in providing meaningful learning activities (Grandy \& Duschl, 2007).

Guided inquiry provides students with the opportunity to be directly involved in learning and also makes it possible to have direct information on the achievement of the objectives set for a particular subject. This strategy has the ability to maximize students' development in discovering appropriate personal learning concepts (Koksal \& Berberoglu, 2014). This, however, the provision of assistance by the teachers through the 1) creation of a peer environment focusing on physical skills, 2) implementation of a learning strategy that allows interaction and working with peers to ensure the development of social personality for the students, 3) formulation of activities with emphasis on providing concrete or immediate experiences in building concept, 4) application of value-developing learning process to ensure the students are self-reliant and independent. 
The results of the observations and interviews with the Principal of Semen Elementary School Temanggung showed there are several problems against the implementation of this strategy and they include lack of appropriate books or teaching materials, boredom and less motivation caused by boring books, poor parents/guardians, and the absence of adequate facilities to meet learning needs. Therefore, in the process of learning Natural Science, students only have the option of listening to the information being passed across by the teacher without any media to aid the learning process.

Based on the importance of the guided inquiry strategy as well as the several challenges being faced by students in Indonesia as previously explained, it is necessary to have an appropriate media to support students' learning process and one of these is the use of the print media. Moreover, educational magazine is an example of the print media with several advantages compared to several others and has also proved to be effective in achieving learning outcomes due to its ease of access, flexibility, provision of new information, inclusion of graphic contents, low cost, and lightweight content with easily understood languages (Rehman, Muhammad, Ashraf, \& Hassan, 2011). It also has the ability to improve students' vocabulary when presented in several languages (Daddi, 2014). Therefore, this research aimed to develop an educational magazine based on the guided inquiry strategy, conduct feasibility tests and trials, and analyze the impact of media usage.

\section{Methodology}

\section{a. Research Model}

A research and development method was adopted from the model developed by Hannafin and Peck and the steps are as shown in the following figure.

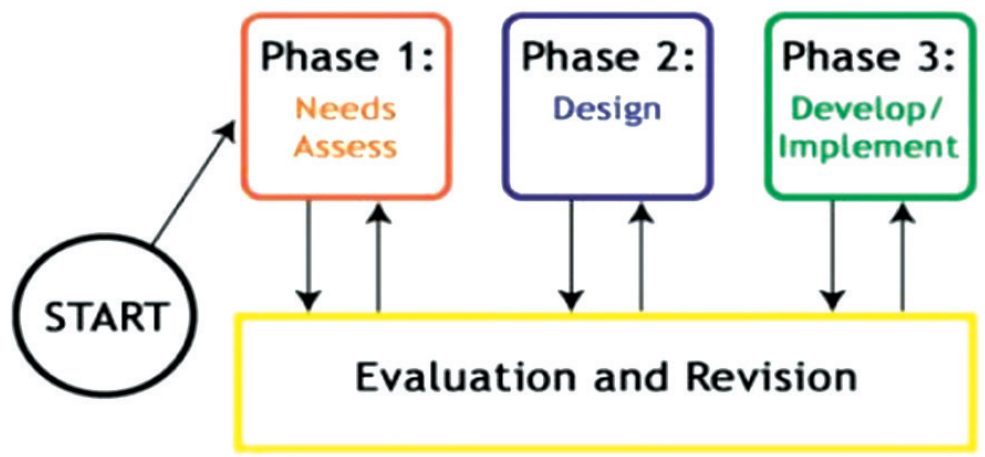

Figure 1. Hannafin and Peck Design Model (Reigeluth, 2013)

The product feasibility test was conducted through the validation of experts on media, natural science materials, and elementary school learning and the product was also 
provided to users, including teachers and students for responses and feedbacks. Moreover, the quasi-experiment was conducted to determine the effectiveness of science magazines based on guided-inquiry on students' understanding.

\section{b. Participants}

This study involved three lecturers with each being an expert on learning media, science, and elementary school, respectively, as reviewers of the proposed science magazine. Moreover, 2 teachers and 12 fifth grade students of Muhammadiyah Sangonan III Elementary School, Yogyakarta, Indonesia were used as respondents for the research trials. Furthermore, the examination included Classroom Action Research conducted on a group consisting of $31 \mathrm{fifth}$ grade students of Semen Elementary School Temanggung, Central Java, Indonesia.

\section{c. Data Collection and Instruments}

Data were collected using questionnaires, interviews, and tests. The questionnaires were used to determine the quality and feasibility of the magazine as a science teaching material through the data retrieved from media, material, and learning experts as well as responses from the teachers and students assessed while the interview was used to obtain deeper qualitative information. Moreover, the tests measured the effectiveness of the magazine in reducing learning difficulties. It is important to note that the teaching material is considered effective if the posttest score is higher than the pretest score.

\section{d. Procedures and Analysis}

This research was conducted in two stages of research and development. The research phase consisted of a preliminary study, a literature review, and an analysis of student learning difficulties. In this stage, a need assessment was conducted to determine the urgency of developing the teaching materials. Meanwhile, the development phase consisted of several steps including 1) design, 2) development, 3) implementation, and 4) evaluation and revision. In the design stage, the storyboard was made to represent the teaching materials and later developed through the addition of some contents using the syntax of the guided inquiry approach. The next step was the conduct of quality and feasibility test by experts and users to determine the quality of the teaching materials after which the accepted ones were applied in science learning for class V. students and their effectiveness was based on the ability to reduce learning difficulties, as indicated by an increase in posttest scores.

The data used in each of the above stages were analyzed based on type and purpose such that qualitative ones were analyzed using an interactive model involving data collection, display, reduction, and conclusion: drawing/verification while descriptive statistics was applied on quantitative data. 


\section{Findings and Discussion}

The aim was to produce a teaching material in the form of a science magazine based on guided inquiry. The development process was preceded by the need assessment conducted to identify the needs for the materials through the use of information from multiple sources. Therefore, the results obtained showed the school is highly in need of interesting additional teaching materials like an educational magazine on Natural Science due to the limited availability of resources and books in schools, unavailability of teachers with different teaching strategies, and inability to maximize surrounding environment as learning sources.

The next stage included the design of the magazine to include components such as Title or Cover, Description, Preface, Developer Profile, Menu or Table of Contents, Main Topics, Standards of Competency, Content Pages including zones for learning, facts, tips, and games, Bibliography, and Back Cover. Moreover, at the development stage, the teaching materials were composed and developed by arranging the media, form, structure, and contents using the syntax of guided inquiry integrated into some parts of the magazine. It involved the teacher providing only the research questions while the students design the procedure to test the questions and the consequent explanations. This means students need guidance in ensuring their plan for investigation is effective through the use of this method (Banchi \& Bell, 2008). The syntax of guided inquiry is shown in Table 1.

\section{Table 1}

The syntax of Guided Inquiry Model

\begin{tabular}{ccl}
\hline Phase & \multicolumn{1}{c}{ Description } \\
\hline 1. & Planning & $\begin{array}{l}\text { The teacher provides issues relating to the students daily life and also } \\
\text { assists in planning the strategy to solve the problem through the use } \\
\text { of an experiment. }\end{array}$ \\
\hline 2. & Retrieving & $\begin{array}{l}\text { Students collect data to solve the problems provided by the teacher } \\
\text { using several learning sources }\end{array}$ \\
\hline 3. & Processing & $\begin{array}{l}\text { Students test and prove the hypothesis by analyzing the experiment } \\
\text { result data }\end{array}$ \\
\hline 4. & Creating & Students make a conclusion on the results of the hypothesis tested \\
\hline 5. & Sharing & $\begin{array}{l}\text { Students present their findings to the class, and the teacher makes } \\
\text { corrections }\end{array}$ \\
\hline 6. & Evaluating & $\begin{array}{l}\text { The teacher appreciates every presentation group and implements the } \\
\text { appropriate corrections to the findings. }\end{array}$ \\
\hline $\begin{array}{l}\text { References: (Espinosa Bueno, Labastida Pina, Padilla, \& Garritz, 2011; Gyllenpalm, Wickman, \& Holmgren, 2010; Pedaste } \\
\text { et al., 2015; Putra, Widodo, \& Jatmiko, 2016) }\end{array}$ \\
The fourth stage was the implementation of the product in Muhammadiyah Sangonan \\
III Elementary School Sleman Yogyakarta as a limited trial, and in Semen Elementary
\end{tabular}


School Temanggung in large-scale. However, several activities preceded the application of this product and the first was the determination of the feasibility of the teaching materials from the perspective of the material, media, and learning. This involved the comment and advice of the learning materials expert, assessment of the existing designs such as fonts, colors, animations, and layer designs by the media professional, as well as the evaluation of its suitability for elementary school students by the expert on learning. This was followed by the conduct of a limited trial on some elementary school students to determine the impact of the developed teaching material and then a large-scale trial was conducted for all research subjects.

The last stage was the evaluation conducted after experts have made suggestions such as the need to put the surrounding environment into consideration, inclusion of games in the magazine as an assessment instrument, and the removal of some animations as well as the adjustment of the design to the existing script on the pages to improve the material. The product was found to be feasible and applicable in reducing learning difficulties for the students in elementary schools with a very good category.

As previously indicated, the qualitative inputs made by the experts are shown in Table 2.

Table 2

Experts' Feedbacks toward Magazine developed based on Guided Inquiry

\section{Feedbacks on teaching materials}

\begin{tabular}{|c|c|}
\hline Media Expert & $\begin{array}{l}\text { - Some layers of the content design need to be improved. } \\
\text { - Some image illustrations need to be omitted. } \\
\text { - Font type and color need to be adjusted. } \\
\text { hinishing or final stage of cutting needs to be modified in a printing } \\
\text { house to ensure the words are not cut off. }\end{array}$ \\
\hline $\begin{array}{l}\text { Natural Science } \\
\text { Material Experts }\end{array}$ & $\begin{array}{l}\text { - The materials in Alit magazine learning media should be adjusted to } \\
\text { the local wisdom of the surrounding community } \\
\text { - Guided Inquiry integration should be emphasized on important } \\
\text { materials } \\
\text { - The plot of materials presentation needs to be made more hierarchi- } \\
\text { cal, from easy to difficult and simple to complex. }\end{array}$ \\
\hline $\begin{array}{l}\text { Elementary School } \\
\text { Learning Expert }\end{array}$ & $\begin{array}{l}\text { - Games zone needs to be added to the magazine } \\
\text { - Guided Inquiry integration should be the main spirit in the learning } \\
\text { syntax with the use of the magazine as a teaching material } \\
\text { Instructions for teachers should emphasize the steps with guided } \\
\text { inquiry }\end{array}$ \\
\hline
\end{tabular}

Therefore, the final product of the Natural Science magazine was improved as shown with the cover in Figure 1 as well as others in Figures 2, 3, and 4. 

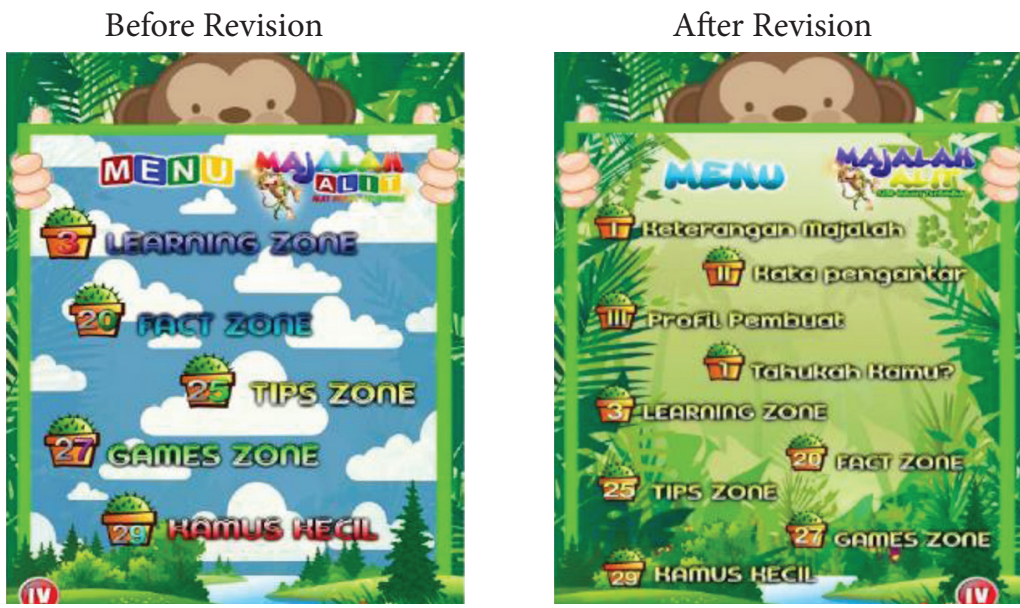

Figure 2. The sample of product revision based on media expert's input

The improvements made on the cover as depicted in Figure 2 include 1) the original sky and cloud layer being fixed to the forest in order to match the material characteristics available in the educational magazine better, 2) font type to ensure uniformity and readability, and 3) color to produce a harmonious impression. Moreover, with reference to the learning material expert, the product improved the page on "fact zone" as shown in Figure 3.
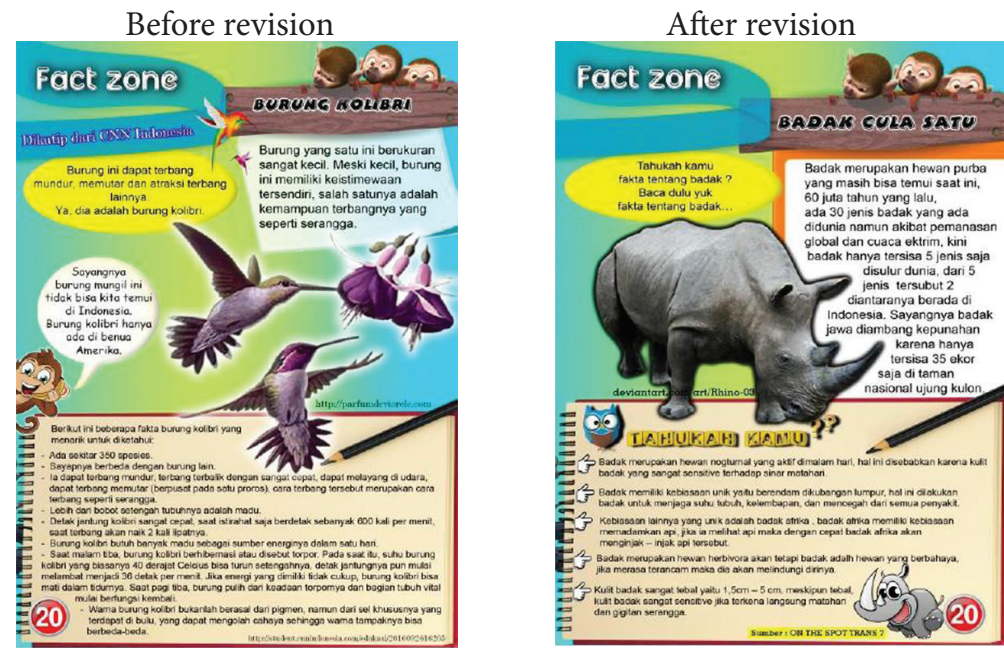

Figure 3. Example of product revision based on the input from Natural Science material expert

Figure 3 shows the original factual information about hummingbirds was replaced by one-horned rhinoceros based on the fact they are a native Indonesian endangered animal and the intention to foster a sense of love for flora and fauna. Furthermore, based on the input of elementary school learning experts shown in Table 2, a GameZone was added 
to the magazine as shown in Figure 4 and used for evaluation as well as a play area to increase students' enthusiasm towards learning.

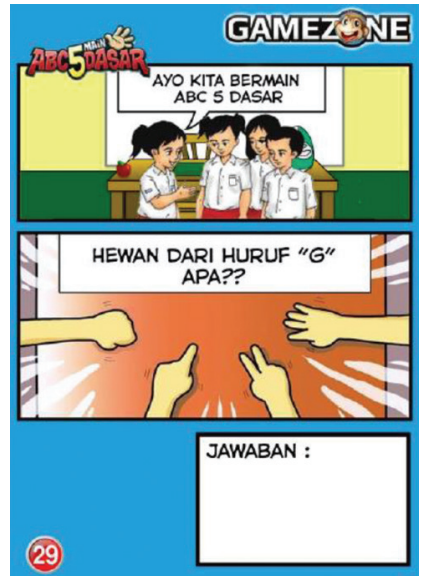

Figure 4. Example of product revision based on input from elementary school learning expert

The final product was tested on students and teachers with the trials conducted in limited and large groups as stated in the methodology section. In the limited group, a teacher and 12 students from Muhammadiyah Sangonan III Elementary School Sleman, Yogyakarta were used as respondents while the large group involved responses from a teacher and 31 students of Semen Elementary School Temanggung, Central Java and the results are presented in Table 3.

Table 3

Results of product feasibility assessment

\begin{tabular}{lccl}
\hline \multicolumn{1}{c}{ Assessment } & Score & Value & Category \\
\hline Material Expert & 34 & 85 & Very feasible \\
\hline Media Expert & 37 & 92,5 & Very feasible \\
\hline Learning Expert & 32 & 80 & Very feasible \\
\hline Limited Scale Trial & & & \\
\hline Teacher Response & 67 & 98,5 & Very feasible \\
\hline Students Response & 119 & 89,0 & Very feasible \\
\hline Large Scale Trial & & & \\
\hline Teacher Response & 143 & 95,33 & Very feasible \\
\hline Students Response & 97 & 97 & Very feasible \\
\hline
\end{tabular}

The pretest and posttest score presented in Table 4 shows the teaching material greatly affect the level of students' understanding of Natural Science, especially with the adjustment of living things to their environment. 
Table 4

Descriptive Analysis of Students' Understanding Before and After the Product

\begin{tabular}{lccccc}
\hline & N & Minimum & Maximum & Mean & Std. Deviation \\
\hline Pre-Test & 31 & 33,00 & 73,00 & 64,0000 & 10,29239 \\
\hline Post-Test & 31 & 53,00 & 100,00 & 78,3871 & 10,52514 \\
\hline Valid N (listwise) & 31 & & & \\
\hline
\end{tabular}

Table 4 shows an increase in the value of the pretest to posttest by 14.39 or $22.48 \%$ for all the students as observed from the distribution of the values in Figure 5.

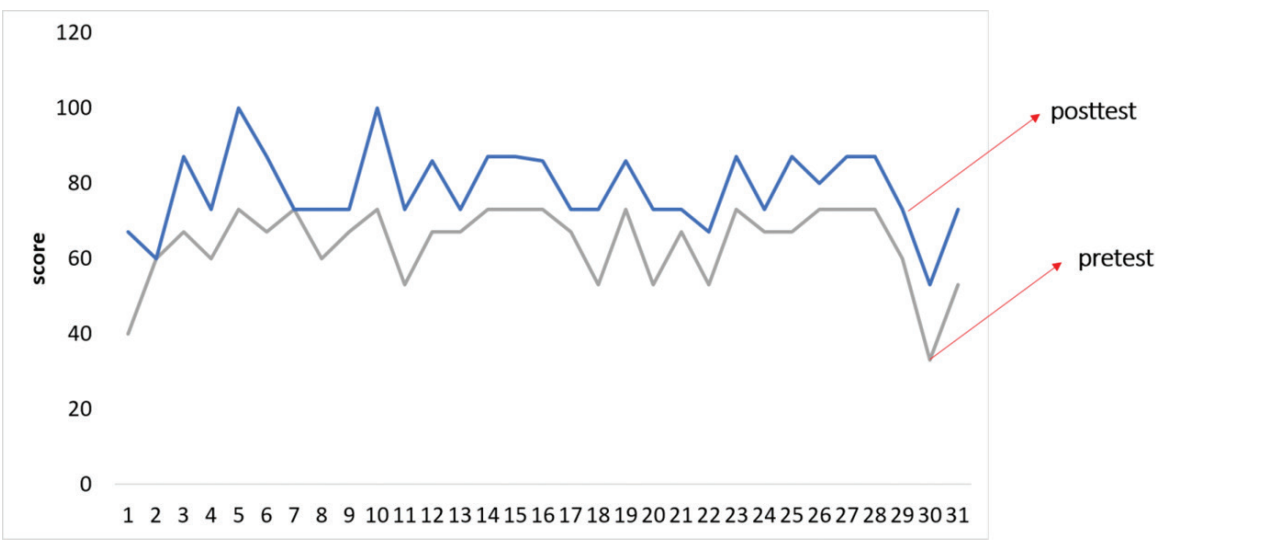

Figure 5. Score Distribution of students' Pretest and Posttest

Figure 5 shows a prevalent increase in each student's understanding and they were all observed to be very enthusiastic during the learning process as indicated by the positive response to the problems presented by the teacher as well as the educational magazine used as the source of the solution. Moreover, the enthusiasm was also shown by the students while assessing the questions in The Gamezone and any time they were faced with difficulties, they seek their teachers' and peers' opinions.

This study successfully tested the impact of the magazine through the comparison of the pretest and posttest scores. The results showed the post-test scores increased by 14.3871 as shown in Table 4 due to the changes in the responses of the students before and after the magazine has been used. The positive disposition of the respondents shows the meaningful effect the inquiry approach has on their learning activities as observed in their ability to construct learning material due to the close relation to their daily lives. In accordance with the findings of previous research that students' interest in science magazines influences the interest to acquire knowledge (Kang \& Keinonen, 2017). Moreover, the guidance provided by the teachers also aids the students' development, especially concerning problem-solving through the use of existing teaching materials. The attitude and self-efficacy of the students were also observed to have improved due to the 
impact of the collaborative learning approach applied by the teachers (Vishnumolakala, Treagust, Mocerino, \& Qureshi, 2017). In addition, the inquiry approach integrated into the educational magazine has the potential to increase students' literacy and confidence (Gormally, Brickman, Hallar, \& Armstrong, 2009).

The Guided Inquiry Design has the ability to guide elementary students through the flow of discovery in the learning process from several sources of information through collaborative learning and inquiry (Maniotes, 2018). This model requires the teachers are involved in lesson planning, material development, monitoring of group discussion, and the motivation of students to ask more questions in the classrooms (Banerjee, 2010) material development, and round-the-year follow-up school visits for a three-year cycle. The professional development improves the ability of teachers to do and understand inquiry. Consequently, teachers organize more guided inquiry labs and post-lab discussion and motivate students to ask more questions in their classrooms. (Contains 6 tables and 3 figures. Moreover, the practice of inquiry-guided learning activities suitable for different courses in the curriculum by the students ensures increasingly independent questioning and knowledge construction. It has also been reported to have the ability of improving the cability of the learners to solve problems and produce different artifacts with little or no supervision (Atkinson \& Hunt, 2008)participants practiced constructing inquiry-guided learning activities suitable for a range of different courses taught throughout the curriculum. These activities are described here. Inquiry-guided learning (IGL.

The construction of scientific knowledge in inquiry-based science classes is a challenging task for students and also requires skillful teachers to support the learning process (Harris \& Rooks, 2010; Wu \& Hsieh, 2006). Furthermore, cognitive and metacognitive attributes have strong links with learners' inquiry processes, especially the planning and analyzing skills. Therefore, science magazine, as an integrated learning resource of inquiry, has the ability to train students starting from the planning to the evaluation of outcomes (Zhang, Hsu, Wang, \& Ho, 2015). It, however, requires more than teaching but also investigative and analytical skills from the teachers (Bryce, Wilmes, \& Bellino, 2015). Moreover, science participation through inquiry influences students' positive attitudes and increases their understanding of the model (Schmidt \& Ketler, 2017). Visual media such as digital images, teaching materials, storybooks, magazines, modules play an important role in inquiry instruction and this makes it important for the teacher to transit to student-centered teaching methods (Maeng, Mulvey, Smetana, \& Bell, 2013). Therefore, the science magazine developed is the starting point for the students towards constructing science concepts and this would be achieved through the guidance of the teacher by reading and investigating scientific phenomena (Bencze, 2009). Some other factors with possible influence include academic levels (Poropat, 2009), achievement motivation (Shaharoun, Awaluddin Mohamed \& Harun, 2012), self-efficacy (Turner, Chandler, \& Heffer., 2009), and teachers' teaching strategies (Ibrahim, Aulls, \& Shore, 2017). 


\section{Conclusion}

This research successfully developed a guided inquiry-based magazine using Hannafin and Peck's design of needs assessment, design, development/implementation, evaluation, and revision. Media, natural science material, and elementary school learning experts evaluated the media and found it to have a good quality of what is expected of science teaching materials for elementary school students. It was discovered to have the ability to help students understand learning material as indicated by the increase in their common understanding before and after the intervention. Moreover, the content and approaches used in magazines have the ability to create meaningful learning processes and help students construct knowledge more efficiently. Therefore, the guided inquiry-based science magazine was concluded to be an appropriate teaching material to reduce student learning difficulties.

\section{References}

Atkinson, M. P., \& Hunt, A. N. (2008). Inquiry-guided Learning in Sociology. Teaching Sociology, 36(1), 1-7. https://doi.org/10.1177/0092055X0803600101

Banchi, H. , \& Bell, R. (2008). Many Levels of Inquiry. Science and Children, 46(2). Retrieved from https://search.proquest.com/docview/236901022/fulltextPDF/B52613AA33CE4225PQ $/ 1$ ?accountid $=31324$

Banerjee, A. (2010). Teaching Science Using Guided Inquiry as the Central Theme: A Professional

Development Model for High School Science Teachers. Science Educator, 19(2), 1-9. Retrieved from http://vuw.summon.serialssolutions.com/link/0/eLvHCXMwTV2xDgIxCO0POOrs D1xSrrR4s7lqHJzOxJUWOjr5_xGMgxPskPfIywNCOEadBW3MhkFptF7IKF4AG4kwFH EZ-_LE9Ub3R65_aF73Yavrdr5Ovz8AkxpZWx0HNvfKR7BASTVrQwdVgsyWs2KPupRZ pS_WlKfBQsA5sd-O0XQIO3a7-Ov9XSuTDwYOKLo

Bencze, J. L. (2009). "Polite Directiveness" in Science Inquiry: a Contradiction in Terms? Cultural

Studies of Science Education, 4(4), 855-864. https://doi.org/10.1007/s11422-009-9194-5

Bryce, N., Wilmes, S. E., \& Bellino, M. (2016). Inquiry Identity and Science Teacher Professional

Development. Cultural Studies of Science Education, 11(11), 2. https://doi.org/10.1007/s11422015-9725-1

Bryce, N., Wilmes, S. E. D., \& Bellino, M. (2015). Inquiry Identity and Science Teacher Professional Development. Cultural Studies of Science Education, 11(2), 235-251. https://doi.org/10.1007/ s11422-015-9725-1

Clark, R., Yates, K., Early, S., \& Moulton, K. (2008). An Analysis of the Failure of Electronic Media and Discovery-based Learning: Evidence for the Performance benefits of Guided Training Methods. Handbook of Training and Improving Workplace Performance, Vol. 1: Instructional Design and Training Delivery (Vol. I). Somerset, New Jersey: Wiley. 
Cohen, P. A., Ebeling, B. J., \& Kulik, J. A. (1981). A Meta-analysis of Outcome Studies of Visualbased Instruction. J, 29(1), 26-36.

Daddi, H. (2014). The Use of Bilingual Magazine as Media to Develop the Students' Vocabulary. Exposure, 4(2), 201-221.

Devine, D., Fahie, D., \& Deirdre, M. (2013). What is 'good teaching'? Teacher beliefs and Practices about Their Teaching. Irish Educational Studies, 31(1), 83-108.

Dewi, E. R., Bundu, P., \& Tahmir, S. (2016). The Influence of the Antecedent Variable on the teachers' Performance through Achievement Motivation in Senior High School. International Journal of Environmental and Science Education, 11(9), 3161-3166. https://doi.org/10.12973/ijese.2016.912a

Durlak, J. A., Weissberg, R. P., Dymnicki, A. B., Taylor, R. D., Schellinger, \& B, K. (2011). The Impact of Enhancing Students' Social and Emotional Learning: A meta- analysis of Schoolbased Universal Interventions. Child Development, 82(1), 405-432.

Eslinger, E., White, B., Frederiksen, J., \& Brobst, J. (2008). Supporting Inquiry Processes with an Interactive Learning Environment: Inquiry Island. Journal of Science Education and Technology, 17(6), 610-617. https://doi.org/10.1007/s10956-008-9130-6

Espinosa Bueno, J., Labastida Piña, D., Padilla, K., \& Garritz, A. (2011). Pedagogical Content Knowledge of Inquiry: An Instrument to Assess It and Its Application to High School InService Science Teachers. US-China Education Review, 8(5), 599-614.

Gillies, R. M., \& Nichols, K. (2015). How to Support Primary Teachers' Implementation of Inquiry: Teachers' Reflections on Teaching Cooperative Inquiry-based Science. Research in Science Education, 45(2), 171-191.

Gormally, C., Brickman, P., Hallar, B., \& Armstrong, N. (2009). Effects of Inquiry-Based Learning on Students' Science Literacy Skills and Confidence. International Journal for the Scholarship of Teaching and Learning, 3(2), 16. https://doi.org/10.20429/ijsotl.2009.030216

Grandy, R., \& Duschl, R. A. (2007). Reconsidering the Character and Role of Inquiry in School Science: Analysis of a Conference. Science \& Education, 16(2), 141-166.

Gyllenpalm, J., Wickman, P.-O., \& Holmgren, S.-O. (2010). Secondary Science Teachers' Selective Traditions and Examples of Inquiry-oriented Approaches. Nordic Studies in Science Education, 6(1), 44-60.

Harris, C. J., \& Rooks, D. L. (2010). Managing Inquiry-Based Science: Challenges in Enacting Complex Science Instruction in Elementary and Middle School Classrooms. Journal of Science Teacher Education, 21(2), 227-240. https://doi.org/10.1007/s10972-009-9172-5

Hossainy, F. N., Zare, H., Hormozi, M., Shaghaghi, F., \& Kaveh, M. H. (2013). Designing and Implementing a Situated Learning Program and Determining Its Impact on the Students' Motivation and Learning. Turkish Online Journal of Distance Education, 13(2), 36-47.

Ibrahim, A., Aulls, M. W., \& Shore, B. M. (2017). Teachers' Roles, Students' Personalities, Inquiry Learning Outcomes, and Practices of Science and Engineering: The Development and Validation of the McGill Attainment Value for Inquiry Engagement Survey in STEM disciplines. International Journal of Science and Mathematics Education, 15(7), 1195-1215. 
Kang, J., \& Keinonen, T. (2017). The Effect of Student-centered Approaches on Students' Interest and Achievement in Science: Relevant Topic-based, Open and Guided Inquiry-based, and Discussion-based Approaches. Research in Science Education, 1-21. https://doi.org/https:// doi.org/10.1007/s11165-016-9590-2

Koerber, S., Mayer, D., Osterhaus, C., Schwippert, K., \& Sodian, B. (2015). The Development of Scientific Thinking in Elementary School: A Comprehensive Inventory. Child Development, 86(1), 327-336.

Koksal, E. A., \& Berberoglu, G. (2014). The Effect of Guided-inquiry Instruction on 6th-grade Turkish students' Achievement, Science Process skills, and Attitudes toward Science. International Journal of Science Education, 36(1), 66-78.

Korakakis, Georgios, E. A. P., Palyvos, J. A., \& Spyrellis, N. (2009). 3D Visualization Types in Multimedia Applications for Science Learning: A Case Study for 8th-grade Students in Greece. Computers \& Education, 52(2), 390-401.

Kunter, M., Klusmann, U., Baumert, J., Richter, D., Voss, T., \& Hachfeld, A. (2013). Professional Competence of Teachers: Effects on Instructional Quality and Student Development. Journal of Educational Psychology, 105(3), 805-820.

Livingstone, S., \& Bovill, M. (2013). Children and Their Changing Media Environment: A European Comparative Study. Routledge.

Maeng, J. L., Mulvey, B. K., Smetana, L. K., \& Bell, R. L. (2013). Preservice Teachers' TPACK: Using Technology to Support Inquiry Instruction. Journal of Science Education and Technology, 22(6), 838-857. https://doi.org/10.1007/s10956-013-9434-z

Maniotes, L. K. (2018). Guided Inquiry Design in Action: Elementary School. Retrieved from https://search.proquest.com/docview/2071228065/66475152335C4EA6PQ/5?accountid=62690 Maryani, I., Husna, N. N., Wangid, M. N., Mustadi, A., \& Vahechart, R. (2018). Learning Difficulties of The 5th Grade elementary School Students in Learning Human And Animal Body Organ. Jurnal Pendidikan IPA Indonesia, 7(1), 96-105. https://doi.org/10.15294/jpii.v7i1.11269

Mushtaq, I., \& Khan, S. N. (2012). Factors Affecting Students' Academic Performance. Global Journal of Management and Business Research, 12(9), 17-19.

Nurseto, T. (2011). Membuat media pembelajaran yang menarik. Jurnal Ekonomi \& Pendidikan, $8(1), 19-35$.

Parmin, Sajidan, Ashadi, Sutikno, \& Maretta, Y. (2016). Preparing Prospective Teachers in Integrating Science and Local Wisdom through Practicing Open Inquiry. Journal of Turkish Science Education, 13(2), 3-14. https://doi.org/10.12973/tused.10163a

Pedaste, M., Mäeots, M., Siiman, L. A., de Jong, T., van Riesen, S. A. N., Kamp, E. T., ... Tsourlidaki, E. (2015). Phases of Inquiry-based Learning: Definitions and the inquiry cycle. Educational Research Review, 14, 47-61. https://doi.org/10.1016/j.edurev.2015.02.003

Perangin-angin, A. B., \& Effendy, J. (2016). The Effect of Learning Motivation on Chinese Language Learning Achievement at STBA-PIA College Student. VISION, 10(10), 5-7.

Poropat, A. E. (2009). A Meta-analysis of the Five-factor Model of Personality and Academic Performance. Psychological Bulletin, 35(2), 322. 
Putra, M. I. S. S., Widodo, W., \& Jatmiko, B. (2016). The Development of Guided Inquiry Science Learning Materials to Improve Science Literacy Skill of Prospective teachers. Jurnal Pendidikan IPA Indonesia, 5(1), 83-93. https://doi.org/10.15294/jpii.v5i1.5794

Ramdhani, M. A., \& Muhammadiyah, H. (2015). The Criteria of Learning Media Selection for Character Education in Higher Education. In Proceeding International Conference of Islamic Education: Reform, Prospects, And Challenges (pp. 174-182). Malang: Faculty of Tarbiyah and Teaching Training, Maulana Malik Ibrahim State Islamic University.

Rehman, F., Muhammad, S., Ashraf, I., \& Hassan, S. (2011). Factors Affecting The Effectiveness Of Print Media In The Dissemination In The Dissemination Of Agricultural Information. Sarhad J. Agric, 27(1), 119-124.

Reigeluth, C. M. (2013). Instructional-Design Theories and Models: A New Paradigm of Instructional Theory (2nd ed.). Routledge.

Reyes, M. R., Brackett, M. A., Rivers, S. E., White, M., \& Salovey, P. (2012). Classroom Emotional Climate, Student Engagement, and Academic Achievement. Journal of Educational Psychology, 104(3), 700-712.

Schmidt, K. M., \& Ketler, P. (2017). Science Fairs: A Qualitative Study of Their Impact on Student Science Inquiry Learning and Attitudes Toward STEM. Science Educator, 25(2), 126-132. Retrieved from https://search.proquest.com/docview/1865491855/fulltextPDF/9093ABBDB FBA46CEPQ/40? accountid $=62690$

Shaharoun, Awaluddin Mohamed, M. P., \& Harun, H. (2012). Does Motivation Affect Students' Understanding and Performance in Engineering Statics? In Procedia-Social and Behavioral Sciences (pp. 191-203.).

Sinaga, P., Karniawati, I., \& Setiawan, A. (2017). Improving Secondary School Students ' Scientific Literacy Ability Through The Design Of Better Science Textbooks. Journal of TurkishScience Education, 14(4), 92-107. https://doi.org/10.12973/tused.10215a

Sinatra, G. M., Heddy, B. C., \& Lombardi, D. (2015). The Challenges of Defining and Measuring Student Engagement in Science. Educational Psychologist, 50(1), 1-13. https://doi.org/10.108 0/00461520.2014.1002924

Turner, E. A., Chandler, M., \& Heffer., R. W. (2009). The Influence of Parenting Styles, Achievement Motivation, and Self-efficacy on Academic Performance in College Students. Journal of College Student Development, 50(3), 337-346.

Vishnumolakala, V. R. D. C. S., Treagust, D. F., Mocerino, M., \& Qureshi, S. (2017). Students' Attitudes, Self-efficacy, and Experiences in a Modified Process-oriented Guided Inquiry Learning Undergraduate Chemistry Classroom. Chemistry Education Research and Practice, 18(2), 340-352.

Wu, H., \& Hsieh, C. (2006). Developing Sixth Graders' Inquiry Skills to Construct Explanations in Inquiry based Learning Environments. International Journal of Science Education, 28(11), 1289-1313. https://doi.org/10.1080/09500690600621035

Zhang, W.-X., Hsu, Y.-S., Wang, C.-Y., \& Ho, Y.-T. (2015). Exploring the Impacts of Cognitive and Metacognitive Prompting on Students' Scientific Inquiry Practices Within an E-Learning 
Environment. International Journal of Science Education, 37(3), 529-553. https://doi.org/10. 1080/09500693.2014.996796

Zubaidah, S., Fuad, N. M., Mahanal, S., \& Suarsini, E. (2017). Improving Creative Thinking Skills of Students through Differentiated Science Inquiry Integrated with Mind Map. Journal of Turkish Science Education, 14(4), 77-91. https://doi.org/10.12973/tused.10214a

\section{Žurnalas, paremtas koordinuotu tyrinèjimu: naujové, skirta ìveikti gamtos mokslų mokymosi sunkumus pradinèse mokyklose}

Ika Maryani ${ }^{1}$, Nurul Wahyu Lestari ${ }^{2}$, Much. Fuad Saifuddin ${ }^{3}$

1 Ika Maryani, M. Pd. Ahmad Dahlan universitetas, Pradinių klasių mokytojų rengimo katedra, Jl. Ki Ageng Pemanahan, Jogjakarta, Indonezija, ika.maryani@pgsd.uad.ac.id.

2. Nurul Wahyu Lestari, S. Pd. Ahmad Dahlan universitetas, Pradinių klasių mokytojų rengimo katedra, Jl. Ki Ageng Pemanahan, Jogjakarta, Indonezija, nurulwahyu241@gmail.com

3 Much. Fuad Saifuddin, M. Pd. Ahmad Dahlan universitetas, Biologijos ugdymo katedra, Jl. Ringroad Selatan,

Tamanan, Jogjakarta, Indonezija, fuad.saifuddin@pbio.uad.ac.id

\section{Santrauka}

Mokinių nesugebejjimas suprasti labai sudètingą dalyko medžiagą sukelia daugiausia problemų. Vienas iš būdų sumažinti šiuos sunkumus - įdiegti mokymosi žiniasklaidos priemonę, kuri mokytojams padètų lengvai perteikti abstrakčią ir sudėtingą dalyko medžiagą. Tikimasi, kad tokia priemonè pradinèse mokyklose leis sukurti prasmingą mokymuisi aplinką, kuri dèl tinkamų mokymosi metodų, siejamų su įdomia žiniasklaida, gali padèti mokiniams lengvai suprasti mokytojo aiškinimus. Tyrimas, kaip svarbi tyrinejjimo proceso dalis, išryškina kritinio ir analitinio mąstymo igūdžius, kurie yra svarbūs aktyviam mokinių dalyvavimui mokymosi procese. Šis tyrimas buvo atliktas tam, kad remiantis koordinuotu tyrinejjimu pagal Hannafino ir Pecko modelị būtų sukurtas žurnalas pradinès mokyklos penktokams; tai pagerintų mokinių gamtos mokslų temų supratimą. Duomenys surinkti naudojant klausimynus, interviu, testus bei išanalizuoti naudojant aprašomąją statistiką ir interaktyvią kokybinę analizę. Ekspertų vertinimai bei mokinių supratimo vidurkis prieš intervenciją ir po jos rodo, kad išleistus mokslo žurnalus galima naudoti kaip mokomąją informacinę priemonę, siekiant ịveikti mokymosi sunkumus ir pagerinti mokinių supratimą.

Esminiai žodžiai: mokslo žurnalas, koordinuotas tyrinejimas, pradinè mokykla. 